\title{
UPAYA PENINGKATAN KINERJA GURU DALAM MENETAPKAN KRITERIA KETUNTASAN MINIMAL MELALUI WORKSHOP
}

\author{
Sri Khasanah ${ }^{1)}$ \\ 1) Sekolah Dasar Negeri 2 Jambu Jepara \\ Jl. Haji Karmani RT.01 RW.01 Kecamatan Mlonggo, Jepara, Jawa Tengah 59452 \\ Email: sri.khasanah67@gmail.com
}

\begin{abstract}
ABSTRAK
Kurikulum berbasis kompetensi menggunakan acuan kriteria dalam penilaian, mengharuskan pendidik dan satuan pendidikan menetapkan kriteria minimal yang menjadi tolok ukur pencapaian kompetensi. Oleh karena itu, diperlukan panduan yang dapat memberikan informasi tentang penetapan kriteria ketuntasan minimal yang dilakukan di satuan pendidikan. Metode yang digunakan dalam penelitian ini adalah metode Penelitian Tindakan Sekolah (PTS). Penelitian ini bertujuan untuk menganalisis dan mendiskripsikan Peningkatan Kinerja Guru dalam Menetapkan Kriteria Ketuntasan Minimal (KKM) Melalui Workshop di SDN 2 Jambu. Subjek penelitian: 6 orang guru SDN 2 Jambu. Strategi penyelesaian masalah yang digunakan adalah melalui workshop. Penilaian kinerja guru dalam menetapkan kriteria ketuntasan minimal di SDN 2 Jambu dapat dilakukan melalui pengamatan dan pemantauan guru dalam kegiatan workshop. Dari hasil analisis diperoleh hasil bahwa, workshop sangat efektif untuk meningkatkan kinerja guru dalam menetapkan KKM, karena guru memiliki kesempatan mendiskusikan secara bersama-sama untuk mengkaji dan memecahkan permasalahan berdasarkan keadaan di lapangan, kemudian dapat memperbaikinya atau melakukan tindak lanjut pada siklus berikutnya secara terus menerus apabila masalah belum terselesaikan. Simpulan yang diperoleh: Pelaksanaan tindakan siklus I sesuai observasi melalui rubrik penilaian KKM, nilainya mencapai nilai 120, yang berarti berada pada kategori baik. Sedangkan pada siklus II hasil observasi melalui rubrik penilaian KKM, nilainya mencapai nilai 156, yang berarti berada pada kategori sangat baik. Oleh karena itu guru perlu selalu mengasah diri dalam menguasai langkah-langkah penetapan KKM dan mengaplikasikannya dalam pelaksanaan dan penilaian pembelajaran.
\end{abstract}

Kata kunci: peningkatan kinerja guru, kriteria ketuntasan minimal, workshop.

\section{PENDAHULUAN}

\section{Latar Belakang}

Undang-Undang No. 20 tahun 2003 tentang Sistem Pendidikan Nasional dan PP No. 19 tahun 2005 tentang Standar Nasional Pendidikan mengamanatkan bahwa kurikulum pada jenjang Pendidikan Dasar dan Menengah dikembangkan oleh setiap satuan pendidikan.

Penetapan kriteria minimal ketuntasan belajar merupakan tahapan awal pelaksanaan penilaian hasil belajar sebagai bagian dari langkah pengembangan Kurikulum Tingkat Satuan Pendidikan. Kurikulum berbasis kompetensi yangmenggunakan acuan kriteria dalam penilaian, mengharuskan pendidik dan satuan pendidikan menetapkan kriteria minimal yang menjadi tolok ukur pencapaian kompetensi. Oleh karena itu, diperlukan panduan yang dapat memberikan informasi tentang penetapan kriteria ketuntasan minimal yang dilakukan di satuan pendidikan. 
Salah satu prinsip penilaian pada kurikulum berbasis kompetensi adalah menggunakan acuan kriteria, yakni menggunakan kriteria tertentu dalam menentukan kelulusan peserta didik. Kriteria paling rendah untuk menyatakan peserta didik mencapai ketuntasan dinamakan KKM.

Kriteria Ketuntasan Minimal (KKM) harus ditetapkan sebelum awal tahun ajaran dimulai. Seberapapun besarnya jumlah peserta didik yang melampaui batas ketuntasan minimal, tidak mengubah keputusan pendidik dalam menyatakan lulus dan tidak lulus pembelajaran. Acuan kriteria tidak diubah secara serta merta karena hasil empirik penilaian. Pada acuan norma, kurva normal sering digunakan untuk menentukan ketuntasan belajar peserta didik jika diperoleh hasil ratarata kurang memuaskan. Nilai akhir sering dikonversi dari kurva normal untuk mendapatkan sejumlah peserta didik yang melebihi nilai 6,0 sesuai proporsi kurva. Acuan kriteria mengharuskan pendidik untuk melakukan tindakan yang tepat terhadap hasil penilaian, yaitu memberikan layanan remedial bagi yang belum tuntas dan atau layanan pengayaan bagi yang sudah melampaui kriteria ketuntasan minimal.

Kriteria ketuntasan minimal ditetapkan oleh satuan pendidikan berdasarkan hasil musyawarah guru mata pelajaran di satuan pendidikan atau beberapa satuan pendidikan yang memiliki karakteristik yang hampir sama. Pertimbangan pendidik atau forum Kelompok Kerja Guru (KKG) secara akademis menjadi pertimbangan utama penetapan KKM.
Kriteria

ketuntasan menunjukkan persentase tingkat pencapaian kompetensi sehingga dinyatakan dengan angka maksimal 100. Angka maksimal 100 merupakan kriteria ketuntasan ideal. Target ketuntasan secara nasional diharapkan mencapai minimal 75. Satuan pendidikan dapat memulai dari kriteria ketuntasan minimal di bawah target nasional kemudian ditingkatkan secara bertahap.

Berdasarkan hasil pengamatan kepala sekolah, masih banyak guru belum mempunyai kemampuan yang seutuhnya dalam menentukan KKM atau Kriteria Ketuntasan Minimal yang merupakan salah satu prinsip penilaian pada kurikulum berbasis kompetensi yang menggunakan acuan kriteria, yakni menggunakan kriteria tertentu dalam menentukan kelulusan peserta didik.

\section{Tujuan Penelitian}

Tujuan yang hendak dicapai agar guru-guru dapat mengerti dan memahami tentang KKM dan dapat meningkatkan kemampuan guru-guru SDN 2 Jambu UPT Dinas Dikpora Kecamatan Mlonggo dalam menetapkan (KKM.

\section{Manfaat Penelitian}

Sedangkan manfaat penelitian dapat memberikan pengalaman belajar bagi guru, karena guru diberikan materi dan latihan menetapkan Kriteria Ketuntasan Minimal sesuai dengan mata pelajarannya. Guru-guru SDN 2 Jambu UPT Dinas Dikpora Kecamatan Mlonggo memiliki kemampuan dalam menetapkan Kriteria Ketuntasan Minimal 
sehingga proses belajar mengajar lebih baik.

\section{TINJAUAN PUSTAKA}

Menurut Mangkunegara (2001: 67) kinerja adalah hasil kerja secara kualitas dan kuantitas yang dicapai oleh seorang pegawai dalam melaksanakan tugasnya sesuai dengan tanggung jawab yang diberikan kepadanya. Tinggi rendahnya kinerja pekerja berkaitan erat dengan sistem pemberian penghargaan yang diterapkan oleh lembaga/organisasi tempat mereka bekerja. Pemberian penghargaan yang tidak tepat dapat berpengaruh terhadap peningkatan kinerja seseorang.

Berkaitan erat dengan kinerja guru di dalam melaksanakan tugasnya sehari-hari sehingga dalam melaksanakan tugasnya guru perlu memiliki tiga kemampuan dasar agar kinerjanya tercapai sebagai berikut: a) kemampuan pribadi meliputi hal-hal yang bersifat fisik seperti tampang, suara, mata atau pandangan, kesehatan, pakaian, pendengaran, dan hal yang bersifat psikis seperti humor, ramah, intelek, sabar, sopan, rajin, kreatif, kepercayaan diri, optimis, kritis, obyektif, dan rasional; b) kemampuan sosial antara lain bersifat terbuka, disiplin, memiliki dedikasi, tanggung jawab, suka menolong, bersifat membangun, tertib, bersifat adil, pemaaf, jujur, demokratis, dan cinta anak didik; c) kemampuan profesional sebagaimana dirumuskan oleh P3G yang meliputi 10 kemampuan profesional guru yaitu: menguasai bidang studi dalam kurikulum sekolah dan menguasai bahan pendalaman/aplikasi bidang studi, mengelola program belajar mengajar, mengelola kelas, menggunakan media dan sumber, menguasai landasan-landasan kependidikan, mengelola interaksi belajar mengajar, menilai prestasi siswa untuk kepentingan pendidikan, mengenal fungsi dan program bimbingan penyuluhan, mengenal dan menyelenggarakan administrasi sekolah, memahami prinsip dan menafsirkan hasil-hasil penelitian pendidikan guna keperluan mengajar.

Kinerja guru adalah persepsi guru terhadap prestasi kerja guru yang berkaitan dengan kualitas kerja, tanggung jawab, kejujuran, kerjasama dan prakarsa. Kompensasi yang diberikan kepada guru sangat berpengaruh pada tingkat kepuasan kerja, motivasi kerja, dan hasil kerja. Apabila kompensasi yang diberikan dengan mempertimbangkan standar kehidupan normal dan dapat memenuhi kebutuhan-kebutuhan guru maka dengan sendirinya akan mempengaruhi semangat kerjanya, yang pada gilirannya akan meningkatkan kualitas setiap pekerjaan yang dilakukan. Hal ini karena tujuan bekerja guru banyak dipengaruhi oleh terpenuhi atau tidaknya kebutuhan minimal kehidupan guru dan keluarganya. Dengan demikian dampaknya adalah meningkatnya perhatian guru secara penuh terhadap profesi dan pekerjaanya. Jika kompensasi yang diberikan semakin besar sehingga kepuasan kerjanya semakin baik. Di sinilah letak pentingnya dalam penelitian ini yaitu kompensasi kerja. kinerja guru ditentukan oleh banyak faktor. Faktor-faktor tersebut secara sendiri-sendiri maupun secara bersamaan ikut berperan menentukan tercapainya kinerja guru yang maksimal. 
Menilai kinerja guru di sekolah bukan sebuah hal yang sederhana. Perlu sebuah komunikasi yang baik di dalam sekolah sendiri untuk membuat sebuah standar penilaian yang baik. Standar penilaian kinerja guru yang baik tidak muncul begitu saja. Perlu diupayakan kesepakatan dari pihak yang akan menilai (kepala sekolah) dan guru yang akan dinilai. Dengan demikian tercapai saling pengertian bahwa proses penilaian kinerja guru, sama sekali bukan untuk mencari-cari kesalahan tetapi semata-mata untuk peningkatan kinerja agar sekolah dapat berjalan lebih baik lagi dalam prakteknya. Serta bagaimana agar sekolah dapat membantu guru agar lebih baik lagi dalam melakukan pembelajaran dikelas.

$\begin{array}{lrr}\text { Guru } & \text { adalah salah } & \text { satu } \\ \text { komponen } & \text { pendidikan } & \text { yang } \\ \text { memegang } & \text { peran penting } & \text { dalam } \\ \text { keberhasilan pendidikan, } & \text { guru }\end{array}$
diharapkan mampu memainkan peran sebagai guru yang ideal. Masyarakat mengharapkan agar 'guru' merupakan sosok yang dapat 'digugu' dan 'ditiru'. Guru juga merupakan salah satu tokoh yang harus dijunjung tinggi, yaitu: 'guru, ratu, wongatua karo' (Tilaar, 2004: 11). Pemerintah sering melakukan berbagai upaya peningkatan kualitas guru, antara lain melAlui pelatihan, seminar, dan lokakarya, bahkan melalui pendidikan formal, dengan menyekolahkan guru pada tingkat yang lebih tinggi. Kendatipun pada pelaksanaannya masih jauh dari harapan. Banyak faktor yang mempengaruhi kinerja guru, tetapi permasalahan dalam makalah ini difokuskan pada peran kepemimpinan kepala sekolah, pemberian kompensasi, kedisiplinan guru, dan pengembangan Sumber Daya Guru (SDM).
Sedangkan salah satu prinsip penilaian pada kurikulum berbasis kompetensi adalah menggunakan acuan kriteria, yakni menggunakan kriteria tertentu dalam menentukan kelulusan peserta didik. Kriteria paling rendah untuk menyatakan peserta didik mencapai ketuntasan dinamakan KKM.

Kriteria Ketuntasan Minimal (KKM) harus ditetapkan sebelum awal tahun ajaran dimulai. Seberapapun besarnya jumlah peserta didik yang melampaui batas ketuntasan minimal, tidak mengubah keputusan pendidik dalam menyatakan lulus dan tidak lulus pembelajaran. Acuan kriteria tidak diubah secara serta merta karena hasil empirik penilaian. Pada acuan norma, kurva normal sering digunakan untuk menentukan ketuntasan belajar peserta didik jika diperoleh hasil ratarata kurang memuaskan. Nilai akhir sering dikonversi dari kurva normal untuk mendapatkan sejumlah peserta didik yang melebihi nilai 6,0 sesuai proporsi kurva. Acuan kriteria mengharuskan pendidik untuk melakukan tindakan yang tepat terhadap hasil penilaian, yaitu memberikan layanan remedial bagi yang belum tuntas dan atau layanan pengayaan bagi yang sudah melampaui kriteria ketuntasan minimal.

Kriteria Ketuntasan Minimal ditetapkan oleh satuan pendidikan berdasarkan hasil musyawarah guru mata pelajaran di satuan pendidikan atau beberapa satuan pendidikan yang memiliki karakteristik yang hampir sama. Pertimbangan pendidik atau forum KKG secara akademis menjadi pertimbangan utama penetapan KKM. 
Hal-hal yang harus diperhatikan dalam penentuan kriteria ketuntasan minimal adalah:

\section{Tingkat Kompleksitas}

Kesulitan/kerumitan setiap indikator, kompetensi dasar, dan standar kompetensi yang harus dicapai oleh peserta didik. Suatu indikator dikatakan memiliki tingkat kompleksitas tinggi, apabila dalam pencapaiannya didukung oleh sekurang-kurangnya satu dari sejumlah kondisi sebagai berikut: a) Guru yang memahami dengan benar kompetensi yang harus dibelajarkan pada peserta didik; b) Guru yang kreatif dan inovatif dengan metode pembelajaran yang bervariasi; c) Gguru yang menguasai pengetahuan dan kemampuan sesuai bidang yang diajarkan; d) Peserta didik dengan kemampuan penalaran tinggi; e) Peserta didik yang cakap/terampil menerapkan konsep; f) Peserta didik yang cermat, kreatif dan inovatif dalam penyelesaian tugas/pekerjaan; g) Waktu yang cukup lama untuk memahami materi tersebut karena memiliki tingkat kesulitan dan kerumitan yang tinggi, sehingga dalam proses pembelajarannya memerlukan pengulangan/latihan; $h$ ) tingkat kemampuan penalaran dan kecermatan yang tinggi agar peserta didik dapat mencapai ketuntasan belajar.

\section{Kemampuan Sumber Daya Pendukung}

Dalam penyelenggaraan pembelajaran pada masing-masing sekolah terdiri dari: a) Sarana dan prasarana pendidikan yang sesuai dengan tuntutan kompetensi yang harus dicapai peserta didik seperti perpustakaan, laboratorium, dan alat/bahan untuk proses pembelajaran; b) Ketersediaan tenaga, manajemen sekolah, dan kepedulian stakeholders sekolah.

Tingkat Kemampuan (Intake) Rata-Rata Peserta Didik di Sekolah yang Bersangkutan

Penetapan intake di kelas dapat didasarkan pada hasil seleksi pada saat penerimaan peserta didik baru, Nilai Ujian Nasional/Sekolah, rapor, tes seleksi masuk atau psikotes; sedangkan penetapan intake di kelas berdasarkan kemampuan peserta didik di kelas sebelumnya.

\section{METODE PENELITIAN}

Metode yang digunakan dalam penelitian ini adalah metode Penelitian Tindakan Sekolah (PTS). Metode ini merupakan suatu prosedur penelitian yang diadaptasi dari Penelitian Tindakan Kelas (PTK). Penelitian tindakan sekolah merupakan: a) Penelitian partisipatoris yang menekankan pada tindakan dan refleksi berdasarkan pertimbangan rasional dan logis untuk melakukan perbaikan terhadap suatu kondisi nyata; b) Memperdalam pemahaman terhadap tindakan yang dilakukan; c) Memperbaiki situasi dan kondisi sekolah/pembelajaran secara praktis" (Depdiknas, 2008: 11 12). Secara singkat, PTS bertujuan untuk mencari pemecahan permasalahan nyata yang terjadi di sekolah-sekolah, sekaligus mencari jawaban ilmiah bagaimana masalahmasalah tersebut bisa dipecahkan melalui suatu tindakan perbaikan.

Prosedur penelitiannya dilakukan secara siklikal. Satu siklus dimulai dari a) Perencanaan awal, b) Pelaksanaan, c) Observasi,

d) 
Refleksi yang dapat dilihat pada diagram berikut ini:

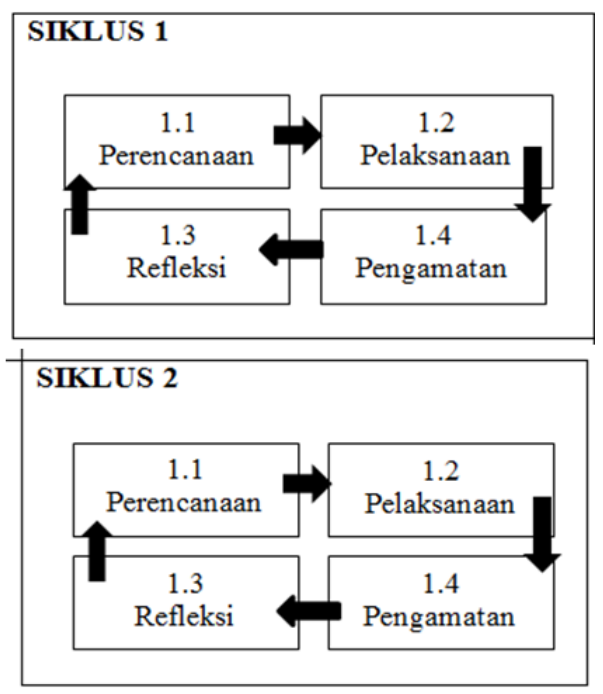

Gambar 1. Prosedur siklus penelitian

\section{Subjek Penelitian}

Subjek penelitian ini adalah guru-guru di SDN 2 Jambu UPT Dinas Dikpora Kecamatan Mlonggo, yang jumlahnya 6 orang guru. Penelitian dilaksanakan pada tahun pembelajaran 2017/2018.

\section{Instrumen dan Alat Pengumpul Data}

Instrumen yang digunakan untuk mengumpulkan data adalah lembar observasi berupa rubrik, yang terdiri dari: a) Rubrik Penilaian KKM. b) Rubrik Penilaian Aktivitas Guru dalam Persiapan Penyusunan KKM. c) Rubrik Penilaian Aktivitas Guru SD dalam Proses Penyusunan KKM. d) Pedoman Wawancara (Diskusi).

\section{Teknik Pengumpulan Data}

Pengumpulan data dilakukan melalui; a) Observasi: Semua kegiatan yang dilakukan untuk mengamati, merekam, dan mendokumentasikan setiap indikator dari proses dan hasil yang dicapai. Dalam observasi ini digunakan (1) Rubrik Penilaian KKM, (2) Rubrik Penilaian Aktivitas Guru SD dalam Persiapan Penyusunan KKM selama Workshop Penyusunan KKM guru di SDN 2 Jambu UPT Dinas Dikpora Kecamatan Mlonggo , dan (3) Rubrik Penilaian Aktivitas Guru SD dalam Proses Penyusunan KKM selama Workshop Penyusunan KKM guru di SDN 2 Jambu UPT Dinas Dikpora Kecamatan Mlonggo . Ketiga rubrik (lembar observasi) ini diformat untuk didisi dengan membubuhkan tanda centang $(\sqrt{ })$ pada kolom nilai 1-4 pada aspek yang dinilai. Tujuan utama dari observasi ini adalah untuk memantau persiapan, proses, hasil, dan dampak perbaikan dari tindakan setiap siklus; b) Wawancara (Diskusi). Wawancara dilakukan melalui diskusi formal dan dialog informal selama berlangsungnya PTS antara peneliti dengan guru-guru Di SDN 2 Jambu UPT Dinas Dikpora Kecamatan Mlonggo dalam kegiatan KKG. Hal ini untuk mengetahui pikiran guruguru yang tidak dapat digali melalui observasi; c) Studi Dokumenter: Sebagai usaha untuk memperoleh data dengan jalan menelaah catatancatatan yang disimpan sebagai dokumen atau files. Teknik ini ditempuh untuk memperoleh datadata mengenai KKM SD dari lembaran-lembaran KKM buatan guru. d) Studi Pustaka: untuk memperoleh data atau informasi dari berbagai tulisan ilmiah baik cetak maupun elektronik yang menunjang penelitian. Teknik ini ditempuh untuk memperoleh pengetahuan yang mendalam mengenai masalah yang diteliti, terutama dalam menentukan arah, metode dan landasan teoritis penelitian. 


\section{HASIL DAN PEMBAHASAN}

\section{Orientasi}

Sebelum melakukan tindakan perbaikan, peneliti terlebih dahulu melakukan kegiatan orientasi sebagai studi pendahuluan. Dalam kegiatan ini guru "didiagnosis" sehingga peneliti menemukan derajat kelengkapan dan kesistematisan KKM yang disusun guru pada saat awal kegiatan. Peneliti mengamati aktivitas guru dalam persiapan dan selama proses penyusunan KKM, kemudian mengevaluasi KKM yang dibuatnya. Hasil pengamatan dan evalusi tersebut kemudian dijadikan bahan untuk mencari upaya perbaikan (tahap tindakan) pada siklus penelitian. Prakteknya, guru-guru Sekolah Dasar diminta menyusun KKM secara spontan tanpa ada intervensi atau berlangsung alami seperti yang mereka lakukan seharihari sebelum mengajar.

Dengan menggunakan Rubrik Penilaian Aktivitas Guru Sekolah Dasar dalam Persiapan Penyusunan KKM selama Workshop Penyusunan KKM di SDN 2 Jambu UPT Dinas Dikpora Kecamatan Mlonggo, diketahui kondisinya sebagai berikut:

Tabel 1. Kondisi sebelum dilakukan tindakan siklus 1

\begin{tabular}{|c|c|c|c|c|c|}
\hline \multirow[t]{2}{*}{ No } & \multirow[t]{2}{*}{ Aspek-aspek yang dinilai } & \multicolumn{4}{|c|}{ Nilai } \\
\hline & & 1 & 2 & 3 & 4 \\
\hline 1 & $\begin{array}{l}\text { Antusiasme guru dalam } \\
\text { mempersiapkan sumber } \\
\text { rujukan penyusunan } \\
\text { KKM }\end{array}$ & $\sqrt{ }$ & & & \\
\hline 2 & $\begin{array}{l}\text { Mengidentifikasi apa } \\
\text { yang harus dipersiapkan } \\
\text { untuk menyusun KKM }\end{array}$ & & $\sqrt{ }$ & & \\
\hline \multicolumn{2}{|c|}{ Jumlah centang } & 1 & 1 & 0 & 0 \\
\hline \multicolumn{2}{|c|}{ Nilai } & 1 & 2 & 3 & 4 \\
\hline \multicolumn{2}{|c|}{$\begin{array}{l}\text { Jumlah Centang X Nilai } \\
\text { Nilai Total }\end{array}$} & 1 & 2 & 0 & $\begin{array}{l}0 \\
3\end{array}$ \\
\hline
\end{tabular}

\begin{tabular}{lcccc}
\hline \multicolumn{1}{c}{ Keterangan } & \multicolumn{4}{c}{ Kategori Nilai Total } \\
\hline $\begin{array}{l}\text { Nilai total } \\
\text { minimum } \\
\text { 1 } 1=2\end{array}$ & Kurang & Cukup & Baik & $\begin{array}{c}\text { Sangat } \\
\text { Baik }\end{array}$ \\
$\begin{array}{l}\text { Nilai total } \\
\text { maksimum : }\end{array}$ & $1-2$ & $3-4$ & $5-6$ & $7-8$ \\
$2 \times 4=8$ & & & & \\
\hline
\end{tabular}

\section{Pelaksanaan Tindakan Perbaikan}

Pelaksanaan Tindakan Perbaikan Siklus 1. Hasil Penilaian melalui Rubrik Penilaian Aktivitas Guru SD dalam Persiapan Penyusunan KKM selama Workshop Penyusunan KKM guru di Negeri 2 Jambu UPT Dinas Dikpora Kecamatan Mlonggo pada Siklus 1 dapat dilihat pada tabel 2:

Tabel 2. Pelaksanaan tindakan siklus 1

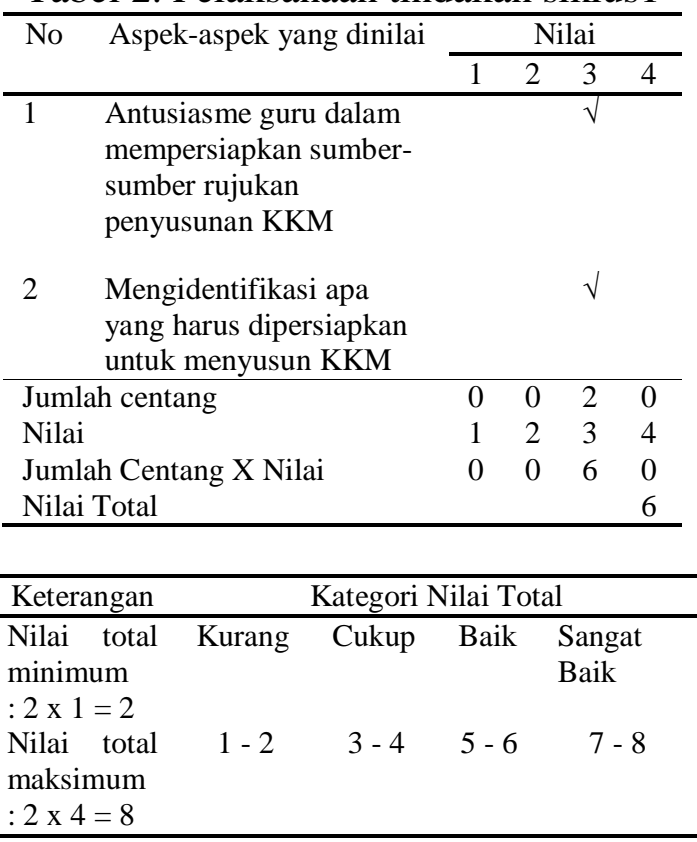

Rubrik Penilaian Aktivitas Guru SD Negeri 2 Jambu dalam Proses Penyusunan KKM selama Workshop Penyusunan KKM pada Siklus 1 dapat dilihat pada tabel 3:

Tabel 3. Rubrik penilaian aktivitas guru siklus 1

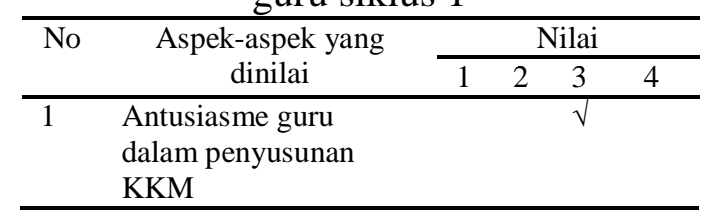




\begin{tabular}{|c|c|c|c|c|c|}
\hline 2 & $\begin{array}{l}\text { Tingkat perhatian pada } \\
\text { peneliti }\end{array}$ & & & $\sqrt{ }$ & \\
\hline 3 & $\begin{array}{l}\text { Keberanian dalam } \\
\text { mengemukakan } \\
\text { pendapat }\end{array}$ & & & $\sqrt{ }$ & \\
\hline 4 & $\begin{array}{l}\text { Keberanian dalam } \\
\text { mengajukan } \\
\text { pertanyaan }\end{array}$ & & & $\sqrt{ }$ & \\
\hline 5 & $\begin{array}{l}\text { Keberanian dalam } \\
\text { menjawab pertanyaan }\end{array}$ & & & $\sqrt{ }$ & \\
\hline 6 & $\begin{array}{l}\text { Kemampuan } \\
\text { bekerjasama atau } \\
\text { berdiskusi }\end{array}$ & & & $\sqrt{ }$ & \\
\hline 7 & $\begin{array}{l}\text { Keberanian tampil di } \\
\text { depan }\end{array}$ & & & $\sqrt{ }$ & \\
\hline 8 & $\begin{array}{l}\text { Ketuntasan } \\
\text { menyelesaikan tugas }\end{array}$ & & & $\sqrt{ }$ & \\
\hline 9 & $\begin{array}{l}\text { Kemauan mencatat } \\
\text { materi yang dianggap } \\
\text { penting }\end{array}$ & & $\sqrt{ }$ & & \\
\hline 10 & $\begin{array}{l}\text { Ketahanan dalam } \\
\text { mengikuti kegiatan } \\
\text { penyusunan KKM }\end{array}$ & & & & $\sqrt{ }$ \\
\hline \multicolumn{2}{|c|}{ Jumlah centang } & 0 & 1 & 8 & 1 \\
\hline \multicolumn{2}{|c|}{ Nilai } & 1 & 2 & 3 & 4 \\
\hline \multicolumn{2}{|c|}{$\begin{array}{l}\text { Jumlah Centang X Nilai } \\
\text { Nilai Total }\end{array}$} & 0 & 2 & 24 & $\begin{array}{l}4 \\
30\end{array}$ \\
\hline
\end{tabular}

Kategori nilai didasarkan pada nilai total yang diperoleh dari hasil perkalian jumlah aspek yang dicentang dari suatu nilai dengan nilai. Karena terdapat 30 aspek, maka nilai total mínimum : $30 \times 1=30$, dan nilai total maksimum : $30 \times 4=120$. Dengan empat kategori nilai, maka diperoleh rentang nilai total untuk tiap kategori nilai seperti dalam tabel 4 berikut ini:

Tabel 4. Rentang nilai Siklus 1

\begin{tabular}{cccc}
\hline Kurang & Cukup & Baik & Sangat Baik \\
\hline $1-40$ & $41-80$ & $81-120$ & $121-160$ \\
\hline
\end{tabular}

Hasil observasi melalui Rubrik Penilaian KKM, nilainya mencapai nilai 120, yang berarti berada pada kategori baik.

Dengan masih terdapatnya halhal tersebut di atas, maka diperlukan langkah perbaikan selanjutnya. Dengan kata lain perlu siklus kedua sehingga perbaikannya optimal.
Pelaksanaan Tindakan Perbaikan Siklus 2. Hasil Penilaian melalui Rubrik Penilaian Aktivitas Guru SD dalam Persiapan Penyusunan KKM selama Workshop Penyusunan KKM di SDN 2 Jambu UPT Dinas Dikpora Kecamatan Mlonggo pada Siklus 2 dapat dilihat pada tabel 5:

Tabel 5. Hasil tindakan Siklus 2

\begin{tabular}{|c|c|c|c|c|c|c|c|}
\hline \multirow[t]{2}{*}{ No } & \multirow{2}{*}{\multicolumn{3}{|c|}{ Aspek-aspek yang dinilai }} & \multicolumn{4}{|c|}{ Nilai } \\
\hline & & & & 1 & 2 & 3 & 4 \\
\hline 1 & \multicolumn{3}{|c|}{$\begin{array}{l}\text { Antusiasme guru dalam } \\
\text { mempersiapkan sumber- } \\
\text { sumber rujukan } \\
\text { penyusunan KKM }\end{array}$} & & & & $\sqrt{ }$ \\
\hline 2 & \multicolumn{3}{|c|}{$\begin{array}{l}\text { Mengidentifikasi apa } \\
\text { yang harus dipersiapkan } \\
\text { untuk menyusun KKM }\end{array}$} & & & & $\sqrt{ }$ \\
\hline \multirow{3}{*}{\multicolumn{4}{|c|}{$\begin{array}{l}\text { Jumlah centang } \\
\text { Nilai } \\
\text { Jumlah Centang X Nilai } \\
\text { Nilai Total } \\
\end{array}$}} & 0 & 0 & 0 & 2 \\
\hline & & & & 1 & 2 & 3 & 4 \\
\hline & & & & 0 & 0 & 6 & $\begin{array}{l}0 \\
8\end{array}$ \\
\hline \multicolumn{2}{|c|}{ Keterangan } & \multicolumn{6}{|c|}{ Kategori Nilai Total } \\
\hline \multicolumn{2}{|c|}{$\begin{array}{l}\text { Nilai total } \\
\text { minimum } \\
: 2 \times 1=2\end{array}$} & Kurang & Cukup & Bail & & \multicolumn{2}{|c|}{$\begin{array}{c}\text { Sangat } \\
\text { Baik }\end{array}$} \\
\hline \multicolumn{2}{|c|}{$\begin{array}{l}\text { Nilai total } \\
\text { maksimum } \\
: 2 \times 4=8\end{array}$} & $1-2$ & $3-4$ & $5-6$ & & & \\
\hline
\end{tabular}

Rubrik Penilaian Aktivitas Guru SD dalam Proses Penyusunan KKM selama Workshop Penyusunan KKM di Negeri 2 Jambu UPT Dinas Dikpora Kecamatan Mlonggo pada Siklus 2 dapat dilihat pada tabel 6:

Tabel 6. Rubrik penilaian aktivitas guru siklus 2

\begin{tabular}{|c|c|c|c|c|}
\hline \multirow[t]{2}{*}{ No } & \multirow{2}{*}{$\begin{array}{c}\text { Aspek-aspek yang } \\
\text { dinilai }\end{array}$} & \multicolumn{3}{|c|}{ Nilai } \\
\hline & & 12 & 3 & 4 \\
\hline 1 & $\begin{array}{l}\text { Antusiasme guru } \\
\text { penyusunan KKM }\end{array}$ & & & $\sqrt{ }$ \\
\hline 2 & $\begin{array}{l}\text { Tingkat perhatian pada } \\
\text { peneliti }\end{array}$ & & & $\sqrt{ }$ \\
\hline 3 & $\begin{array}{l}\text { Keberanian dalam } \\
\text { mengemukakan } \\
\text { pendapat }\end{array}$ & & $\sqrt{ }$ & \\
\hline 4 & $\begin{array}{l}\text { Keberanian dalam } \\
\text { mengajukan pertanyaan }\end{array}$ & & $\sqrt{ }$ & \\
\hline 5 & $\begin{array}{l}\text { Keberanian dalam } \\
\text { menjawab pertanyaan }\end{array}$ & & $\sqrt{ }$ & \\
\hline
\end{tabular}




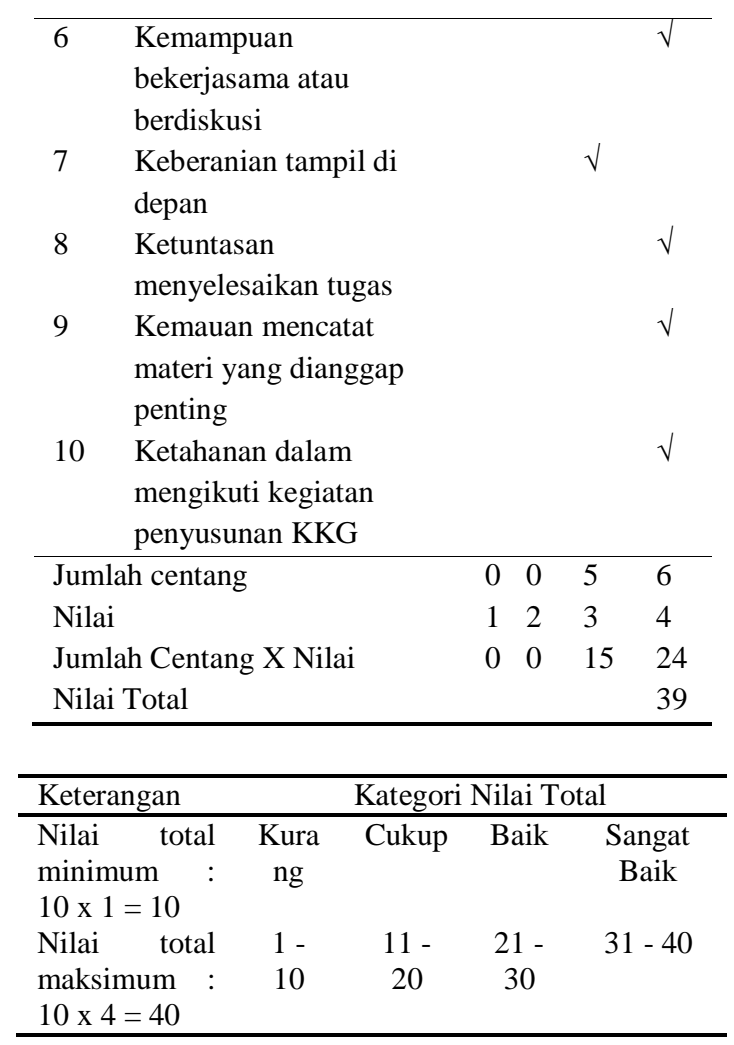

Kategori nilai didasarkan pada nilai total yang diperoleh dari hasil perkalian jumlah aspek yang dicentang dari suatu nilai dengan nilai. Karena terdapat 39 aspek, maka nilai total mínimum : 39 × $1=39$, dan nilai total maksimum : $39 \times 4=16$. Dengan empat kategori nilai, maka diperoleh rentang nilai total untuk tiap kategori nilai sebagai berikut dapat dilihat pada tabel 7:

Tabel 7. Rentang nilai Siklus 2

\begin{tabular}{cccc}
\hline Kurang & Cukup & Baik & Sangat Baik \\
\hline $1-40$ & $41-80$ & $81-120$ & $121-160$ \\
\hline
\end{tabular}

Hasil observasi melalui Rubrik Penilaian Kriteria Ketuntasan Minimal (KKM), nilainya mencapai nilai 156, yang berarti berada pada kategori sangat baik.

Melalui Rubrik Penilaian Aktivitas Guru dalam Proses Penyusunan Kriteria Ketuntasan Minimal (KKM) selama Workshop
Penyusunan KKM di Negeri 2 Jambu UPT Dinas Dikpora Kecamatan Mlonggo, diketahui bahwa pada siklus kesatu hasil observasi melalui rubrik penilaian Kriteria Ketuntasan Minimal (KKM) mencapai nilai 120 atau tergolong baik, dan pada siklus kedua mencapai nilai 156, yang berarti tergolong sangat baik. Hal ini menunjukkan bahwa keterlibatan guru dalam kegiatan tersebut meningkat. Walaupun pada awalnya mereka agak enggan karena membuat KKM itu membosankan, namun setelah mengetahui bahwa pada KKM yang mereka susun terdapat banyak kekurangan, dan setelah peneliti menempatkan diri sebagai nara sumber sesuai permintaan mereka untuk menjelaskan berbagai kekurangan dan menje;askan petunjuk untuk melengkapinya, mereka menjadi lebih antusias dan berusaha lebih keras untuk menyusun sendiri KKM yang lengkap dan sistematis seperti yang mereka tunjukkan pada tindakan perbaikan siklus kedua.

Dari hasil wawancara (diskusi dan dialog) dengan guru-guru peserta kegiatan penyusunan KKM SD melalui pemberdayaan sekolah, diperoleh keterangan bahwa yang menjadi kendala dalam menyusun KKM yang lengkap dan sistematis antara lain: a) Kurangnya sumbersumber rujukan penyusunan KKM yang mereka miliki. b) Kurangnya pengetahuan tentang komponenkomponen KKM baik yang minimal sesuai tuntutan Permendiknas Nomor 41 Tahun 2007 tentang Standar Proses, maupun komponenkomponen tambahan yang bisa melengkapi KKM, sebagai akibat dari (1) kurangnya sumber rujukan yang dimiliki (kendala pertama), dan (2) 
betapapun mereka memilikinya, tapi mereka jarang atau tidak membacanya. c) Kurang kreatifitas untuk membuat KKM menurut pendapat sendiri dengan menafsirkan langsung dari sumber rujukan.

Jawaban-jawaban terhadap rumusan masalah ini menunjukkan bahwa belajar bersama jika dikelola dengan baik memungkinkan pengalaman belajarnya diserap oleh seluruh peserta (kooperatif, kolaboratif, bermakna). Untuk materi pembelajaran yang memerlukan pemahaman yang sama, belajar bersama yang melibatkan kegiatan, sharing, cooperative learning, diskusi dan sebagainya, memungkinkan materi pelajaran tersebut dikonstruksi bersama. Prinsip saling asah dan saling asuh pun terjadi dengan tak terasa. Prinsip inilah yang menunjukkan berlakunya teori belajar konstruktivisme dalam kegiatan tersebut. Studi suatu Ilmu pengetahuan secara bersama-sama memungkinkan dikonstruksi lebih cepat dan komprehensif, dengan volume masukan yang besar pula (belajar bermakna).

\section{SIMPULAN}

Berdasarkan hasil penelitian mengenai Peningkatan Kompetensi Pedagogik Guru Sekolah Dasar dalam Menyusunan KKM melalui Workshop Penyusunan KKM di SDN 2 Jambu UPT Dinas Dikpora
Kecamatan Mlonggo, diperoleh kesimpulan sebagai berikut:

1. Terjadi peningkatan kompetensi pedagogik Guru Sekolah Dasar dalam menyusun KKM melalui workshop pada kegiatan di SDN 2 Jambu UPT Dinas Dikpora Kecamatan Mlonggo.

2. Aktivitas guru dalam mengikuti workshop penyusunan KKM yang lengkap dan sistematis pada siklus kedua lebih baik daripada pada saat siklus kesatu.

\section{DAFTAR PUSTAKA}

Depdiknas. 2003. Undang-Undang Sistem Pendidikan Nasional. Jakarta: Departemen Pendidikan Nasional.

Depdiknas. 2008. Kurikulum Tingkat Satuan Pendidikan. Jakarta: Dikmenum Depdiknas.

Mangkunegara, Anwar Prabu. 2001. Manajemen Sumber Daya Manusia Perusahaan. Bandung: PT Remaja Rosdakarya.

Peraturan Pemerintah Nomor 19 Tahun 2005 tentang Standar Nasional Pendidikan (SNP).

Tilaar, H.A.R. 2004. Multikulturalisme tantangantantangan global masa depan dalam transformsi pendidikan nasional. Jakarta: Grasindo. 